\title{
Performance of exporting shrimps and dry fishes from Bangladesh
}

\author{
B. R. Sen*, T. Islam, K. Alam and F. Hassan ${ }^{1}$ \\ Department of Economics and Poverty Studies, Noakhali Science and Technology University, Sonapur, Noakhali- \\ 3814 and ${ }^{1}$ Department of Agricultural Statistics, Bangladesh Agricultural University, Mymensingh-2202, Bangladesh \\ *E-mail: ranibinata@gmail.com
}

\begin{abstract}
This study shows the present status of exporting shrimps and dry fishes from Bangladesh in the pre-and -post liberalization period, estimates the growth rate and instability of exporting shrimps and dry fishes for earnings, quantity \& price for five years. Recent status presents that farming of shrimp and processing of dry fish are increasing over the year. Status of exporting shrimp \& dry fish (value, volume \& price) are decreasing in recent years compared to previous years. The overall estimated growth of exported shrimp and dry fish (value) were found $19.48 \%$ and $16.53 \%$ and (volume) were found $11.52 \%$ and $12.86 \%$, respectively. On the other hand, overall estimated export growth of shrimp \& dry fish (price) were $175.94 \%$ and $37.58 \%$, respectively. Instability in shrimp export earnings was found the highest in period I which was $62.16 \%$ and the lowest in period II which was $12.56 \%$. Dry fish export instability was the highest for period I which was $128.08 \%$ \& the lowest percentage was $54.49 \%$ in period II. Instability in quantity export of shrimp was found the highest in period I at $63.29 \%$ whereas it was $155.92 \%$ in period I for dry fish export and the lowest percentage for both were $14.5 \%$ \& $48.66 \%$ in period II, respectively. On the other hand, instability in prices of exported shrimp \& dry fish were found the highest in period I which were $25.26 \% \& 140.63 \%$, respectively. The lowest percentage for shrimp in period II which was $11.29 \%$ and for dry fish it was $63.56 \%$ in period III. It also affects export of shrimp \& dry fish from Bangladesh. The circumstances of shrimp \& dry fish export demand different institutional supports to enhance the marketing activities and to strengthen the competitive position in the international market with a view to ensuring more contribution to our economy.
\end{abstract}

Keywords: Growth rate, Instability, Shrimp export, Dry fish export

\section{Introduction}

Bangladesh is a tropical country covering a land area of 147 thousand sq. $\mathrm{km}$. The country is situated on the north-eastern side of the South Asia and bounded by India on the west, north and east, by Myanmar on the east and by the Bay of Bengal on the south. In our country, agriculture (excluding forestry) contributes 18.32 percent of GDP during 2010-11 (BBS, 2011), and 47\% of the total labor force are engaged in agriculture. The majority of the population who live in the rural areas depend on the primary sector for their livelihood. However, the contribution of the primary sector to GDP has declined from $31.7 \%$ in 1980 to 21.27 in 2010-11, while that of the tertiary sector (services) has grown from 47.4 percent to 58.7 percent during the same period. The water body in Bangladesh is suited for the production of fish, the most important resource of the freshwater ecosystem. Bangladesh ranks third among the world's largest inland fish producing countries after China and India. Fish is the major source of animal protein consumption in Bangladesh contributing about 60 percent of the per capita protein intake in the diet of the people of Bangladesh. Total water area under inland fisheries is about 5.3 million hectares, of which 92.27 percent is open water and the rest 7.73 percent is closed water (DoF, 2011). Total fish production in 2009-10 was 2.89 million tons, whereas this production was raised to 3.06 million tons in 2010-11. During the last few years, the production from open water and marine were also satisfactory. Due to expansion of community based fish culture in the open water and conservation of hilsha fishery, the production raised up to around 57 percent in 2009-10 in comparison to 2003-04. The economy of Bangladesh is primarily dependent on agriculture. The scope of modern agriculture has been widened significantly.

Fishery sub-sector has been playing a vital role in the socio-economic context of Bangladesh. It has been contributing to the development of agro-based industries and creating employment opportunities for rural people. Frozen shrimp of coastal area, fish and fishery products occupy the third position in the country's export (DoF, 2010). Fishery sector accounts for 5.0 percent of GDP of the country in 2004-05, which decreased to 4.43 percent in 2010-11. Bangladesh earns every year a considerable amount of foreign exchange by exporting fish and fish products. The main items of fisheries exports are frozen shrimp and frozen fish. The position of fish and fish products was third in the list of exporting products from Bangladesh (DoF, 2009). 
Performance of exporting shrimps and dry fishes

Shrimp sector is the second largest export sector of Bangladesh after readymade garments (RMG) with a share of about 5 percent in Bangladesh's total exports in the 1990s. In 2003 shrimp exports amounted to US\$ 297.04 million which was 4.54 percent of total exports. In terms of contribution to the GDP, the share was 0.48 percent in 2003 compared to 0.36 percent in 1993. The share of shrimp exports in the total exports income from fish and fish products was 89.98 percent in 2003.

Dry fish sector is also an important sector for our economy. Marine dried fish export plays also an important role in the economy of Bangladesh, contributing to increased foreign exchange earnings. Hossain and Islam (1999) predicted that Bangladesh is able to increase foreign exchange earnings of Tk 50000 million annually by converting $25 \%$ of her existing shrimp cultivable land into semi-intensive farming. Keeping in view the aforesaid facts, the present study was undertaken with the objective to estimate the growth rate and instability of earning from shrimp export in post-war, pre- and post-trade liberalization periods of Bangladesh.

\section{Materials and Methods}

The present study was conducted using secondary data on shrimp \& dry fish export earnings from Bangladesh during the period of 1972-73 to 2009-10. Data were collected from various publications of Bangladesh Bureau of Statistics (BBS, from 1972-1973 to 2009-10). This is the only government level institute responsible for collecting and storing necessary data required for future planning and development of the country.

In this study, growth rate of shrimp and dry fish export (for both earning and quantity) from Bangladesh has been estimated by fitting exponential function for different periods. Instabilities in shrimp \& dry fish export (for both earning and quantity exported) from Bangladesh have been estimated by instability index based on standard deviation of logarithmic change. For forecasting purpose, quantities of and earnings from shrimp \& dry fish export from Bangladesh have been estimated by using deterministic models.

\section{Analytical procedure}

The collected data were analyzed using SPSS and Microsoft Excel programmers. Different methods of analysis were employed in accordance with the objectives of the study. Brief description of the analytical techniques is given below:

\section{Measurement of growth rates of shrimp \& dry fish export}

There are alternative methods by which the growth rate can be calculated for a specified data series. In this study, the growth rates of shrimp \& dry fish exports from Bangladesh were estimated by fitting exponential functions. A simple growth model that regressed dependent variable $(Y)$ on time $(t)$ can be presented by the following equation:

$\mathrm{Y}=\mathrm{a} \mathrm{e}^{\mathrm{bt}+\mathrm{u}}$

Where, $a$ and $b$ are parameters to be estimated, and $e$ is the natural log. It is necessary to linearize this equation in order to apply the classical regression model. This may be accomplished by taking the log of both sides (David, 1982);

$\ln Y=\ln a+b t+u$

Where,

In $\mathrm{Y}=$ Natural log of exports of shrimp or dry fish, $\mathrm{t}=$ Time, $\mathrm{a}=$ Intercept, $\mathrm{b}=$ Coefficient, $\mathrm{u}=$ Error $\left(e^{b}-1\right)^{*} 100$ is the compound growth rate in percentage.

The equation is generally used on the consideration that the change in shrimp \& dry fish exports in a given year would depend upon the shrimp \& dry fish exports in the preceding year. It has a limitation in that it assumes a uniform rate of growth over the entire period under consideration, which may not be true in reality. To study changes in the rate of growth and also in the magnitude of instability, the time period have been divided into different phases in order to calculate the growth rate and to measure instability in 
shrimp \& dry fish (for value, volume \& price) exports from Bangladesh. So, for better understanding, the time period has been divided into different phases as:

(i) Post-war period (1972-73 to 1982-83), (ii) Pre-trade liberalization period (1983-84 to 1992-93), (iii) Post-trade liberalization period (1993-94 to 2009-10), (iv) Overall period (1972-73 to 2009-10)

\section{Measurement of instability in shrimp \& dry fish exports}

Instability in export can be defined as the state in which export continue to change with the passage of time. The extent of instability has to be examined in relation to time. The measure of instability/volatility in time series data requires an explicit assumption of what constitute the acceptable and unacceptable components. A systematic component which can be predicted does not constitute instability and hence, it should be eliminated from data. The remaining unpredictable component represents the instability.

At first we have to calculate log of export earning, then changes over previous years have to estimate. Finally, standard deviation of the percentage for years was calculated. Average of all standard deviations in a period multiplied by 100 is considered as instability for that period. The formula for instability is given below.

$$
\mathrm{I}=\mathrm{SD}\left(\mathrm{a} \log \llbracket X_{\Perp} i / X_{1}(i-1) \rrbracket\right) \times 100
$$

Where, I = Instability index,

$\mathrm{SD}=$ Standard deviation

$X_{i}=$ Export earnings/quantity/prices of shrimp or dry fish in $i^{\text {th }}$ year.

The instability in export earnings, quantity and price of shrimp \& dry fish were estimated by using the above index. Thus, instability index captures both explained and unexplained variation of the concerned variable and should better reflect the true instability situation.

\section{Results and Discussion}

\section{Shrimp exports from Bangladesh}

Shrimp sector is one of the important export sectors of Bangladesh after readymade garments (RMG) and jute and jute goods with a share of about 5 percent in Bangladesh's total exports in the 1990s. In 2009-10 shrimp exports amounted to Tk 22664.593 million which was 2.11 percent of total exports. In terms of contribution to the GDP, the share was 0.48 percent in 2009-10 compared to 0.36 percent in 2008-09. The share of shrimp export in total export income from fish and fish products was 80.63 percent in 200910 (Appendix 1). Its importance is highlighted by the fact that it constitutes more than 70 percent of the export of primary products from Bangladesh. Most shrimps are sold frozen and marketed based on their categorization of presentation, grading, color, and uniformity.

\section{Growth rates of export earnings from shrimp and dry fish in different periods}

To estimate the growth rate of shrimp and dry fish export (value, volume \& price) from Bangladesh, compound functions has been used. Export earnings from shrimp increased at $19.48 \%$ per annum during the whole study period ranged from $52.65 \%$ in period I (1972-73 to 1982-83) to $8.98 \%$ in period III (199394 to 2009-10), reveal that growth rate has declined substantially in the recent past whereas export earnings from dry fish export grew at $16.53 \%$ per annum during the whole study period which ranged from $105.24 \%$ in period I to $-8.79 \%$ in period III, reveal that growth rate has decreased substantially in the recent past. Government should examine the present export strategy in order to increase the export earning share from shrimp and dry fish in Bangladesh.

The compound growth rate of quantity export of shrimp increased at $11.52 \%$ per annum during the whole study period. Export growth decreased from $43.48 \%$ to $8.65 \%$ during Period I and Period II respectively and next period it decreased to $5.65 \%$ whereas growth rate of quantity export from dry fish was found increasing at $12.86 \%$ during the whole study period. It was also found that in period I the growth rate was very high which was $81.85 \%$ but in the next period it became $8.65 \%$. And in period III, it was very low which was $0.40 \%$. 


\section{Export earnings (values in million Tk.)}

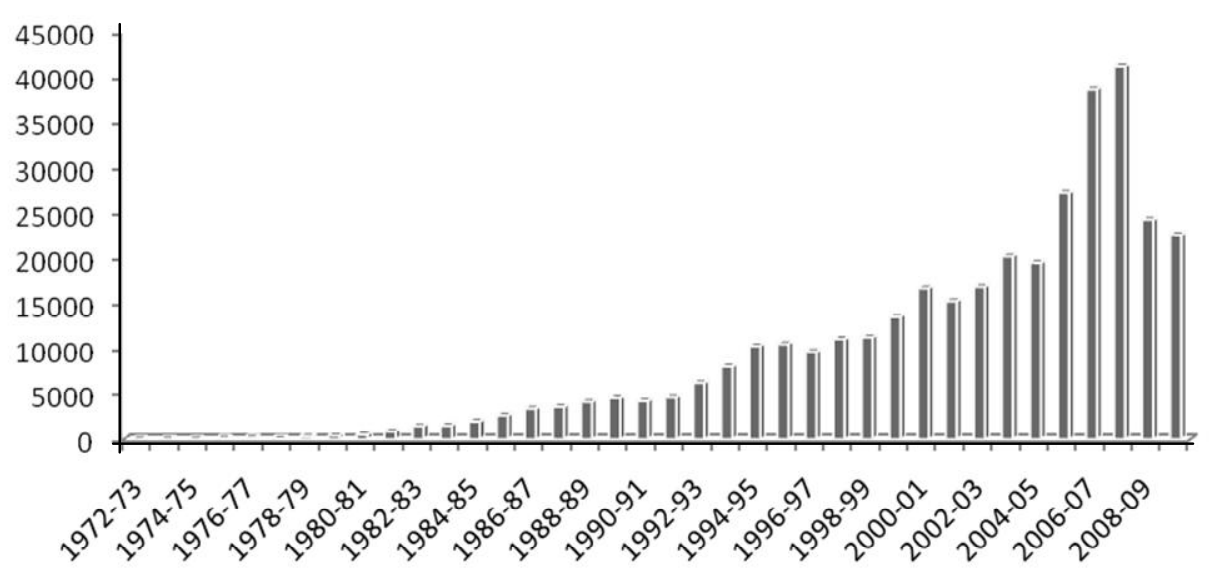

Fig. 1. Total export earnings of shrimp (value) from Bangladesh during 1972-73 to 2009-10

\section{Export earnings (values in million Tk.)}

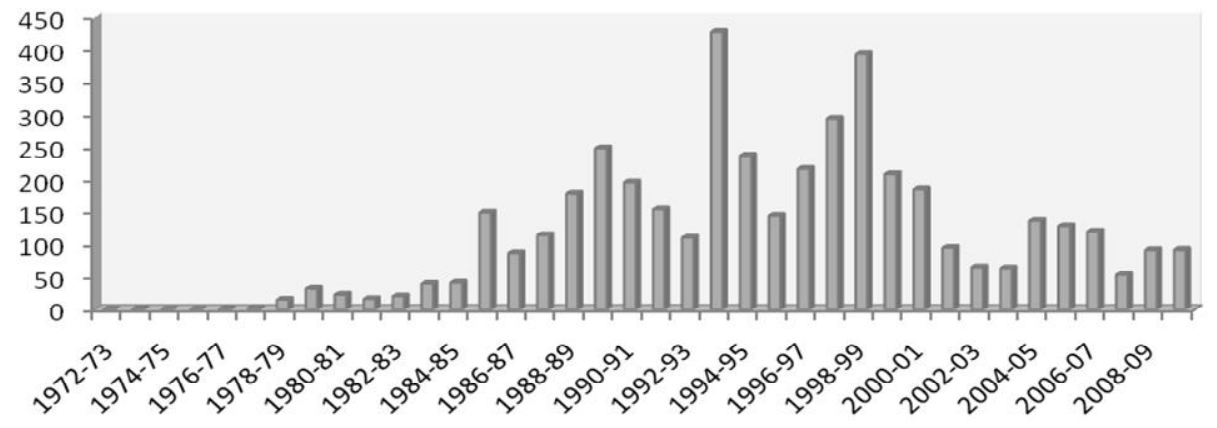

Fig. 2. Total export earnings of dry fish (value) from Bangladesh in 1972-73 to 2009-10

Table 1. Export of shrimp and dry fish in different periods of Bangladesh

\begin{tabular}{lcccc}
\hline \multicolumn{1}{c}{ Particulars } & $\begin{array}{c}\text { Post-war period } \\
(1972-73 \text { to } \\
1982-83)\end{array}$ & $\begin{array}{c}\text { Pre-trade } \\
\text { liberalization period } \\
(1983-84 \text { to 1992-93) }\end{array}$ & $\begin{array}{c}\text { Post-trade } \\
\text { liberalization period } \\
(1993-94 \text { to 2009-10) }\end{array}$ & $\begin{array}{c}\text { Overall period } \\
(1972-73 \text { to } \\
2009-10)\end{array}$ \\
\hline Average total export (million Tk) & 8069.523 & 45886.14 & 425538.2 & 204783.6 \\
Average total frozen food export (million Tk) & 481.6311 & 4127.728 & 20996.88 & 11002.51 \\
Average shrimp export (million Tk) & 390.0364 & 3723.533 & 18718.6 & 9466.893 \\
Average dry fish export (million Tk) & 10.35827 & 132.7293 & 174.5326 & 116.0076 \\
Shrimp export as \% of total export & 4.433 & 8.115 & 4.40 & 4.623 \\
Shrimp export as \% of frozen food export & 80.982 & 90.208 & 89.149 & 4.623 \\
Dry fish export as \% of total export & 0.128 & 0.289 & 0.041 & 0.0566 \\
Dry fish export as \% frozen food export & 2.151 & 3.216 & 0.831 & 1.054 \\
Frozen food export as \% of total export & 5.969 & 8.996 & 4.934 & 5.373 \\
\hline
\end{tabular}

Source: Author's own calculation data from EPB (2009-10). 
Table 2. Growth rate (in \%) of export earnings from shrimp and dry fish (value, volume and prices) in different periods from Bangladesh

\begin{tabular}{lcccc}
\hline \multicolumn{1}{c}{ Variables } & $\begin{array}{c}\text { Post-war period } \\
(1972-73 \text { to } \\
1982-83)\end{array}$ & $\begin{array}{c}\text { Pre-trade } \\
\text { liberalization period } \\
(1983-84 \text { to 1992-93) }\end{array}$ & $\begin{array}{c}\text { Post-trade } \\
\text { liberalization period } \\
(1993-94 \text { to 2005-06) }\end{array}$ & $\begin{array}{c}\text { Overall period } \\
(1972-73 \text { to } \\
2009-10)\end{array}$ \\
\hline Shrimp export (Value) & $52.65 \%$ & $14.11 \%$ & $8.98 \%$ & $19.48 \%$ \\
Shrimp export (Volume) & $43.48 \%$ & $8.65 \%$ & $5.65 \%$ & $11.52 \%$ \\
Shrimp export (Price) & $21.05 \%$ & $50.38 \%$ & $-37.56 \%$ & $37.58 \%$ \\
Dry fish export (Value) & $105.24 \%$ & $15.03 \%$ & $-8.79 \%$ & $16.53 \%$ \\
Dry fish export (Volume) & $81.85 \%$ & $8.65 \%$ & $0.40 \%$ & $12.86 \%$ \\
Dry fish export (Price) & $466.33 \%$ & $4268.48 \%$ & $3908.49 \%$ & $175.94 \%$ \\
\hline
\end{tabular}

On the other hand, compound growth rate of shrimp export price increased at $37.58 \%$ per annum during the whole study period. In period I, it was $21.05 \%$, in period II it increased to $50.38 \%$ and after words it decreased to $-37.56 \%$. Growth rate of export price of dry fish was found increasing at $175.94 \%$ during the whole study period. It was also found that in period I, it was $466.33 \%$, in period II, it was increased rapidly to $4268.48 \%$ and in the last period it was decreased to $3908.49 \%$.

\section{Instability in shrimp \& dry fish exports in different periods}

Instability is one of the important decision parameters in the context of agricultural export because of the fact that shrimp and dry fish exports instability or uncertainty affects our whole earnings a lot. Such knowledge of instability will be very helpful to take necessary steps to increase shrimp and dry fish exports from Bangladesh. The instability indices of shrimp and dry fish exports from Bangladesh were estimated based on standard deviations and its percentage.

Table 3. Measurement of Instability in export of shrimp and dry fishes from Bangladesh in different periods

\begin{tabular}{lcccc}
\hline \multicolumn{1}{c}{ Variables } & $\begin{array}{c}\text { Post-war period } \\
(1972-73 \text { to } \\
1982-83)\end{array}$ & $\begin{array}{c}\text { Pre-trade } \\
\text { liberalization period } \\
(1983-84 \text { to 1992-93) }\end{array}$ & $\begin{array}{c}\text { Post-trade } \\
\text { liberalization period } \\
(1993-94 \text { to 2005-06) }\end{array}$ & $\begin{array}{c}\text { Overall period } \\
(1972-73 \text { to } \\
2009-10)\end{array}$ \\
\hline Shrimp export (Value) & $62.16 \%$ & $12.56 \%$ & $20.92 \%$ & $37.60 \%$ \\
Shrimp export (Volume) & $63.29 \%$ & $14.5 \%$ & $21.49 \%$ & $38.16 \%$ \\
Shrimp export (Price) & $25.26 \%$ & $11.29 \%$ & $14.45 \%$ & $16.89 \%$ \\
Dry fish export (Value) & $128.08 \%$ & $54.49 \%$ & $57.29 \%$ & $84.96 \%$ \\
Dry fish export (Volume) & $155.92 \%$ & $48.66 \%$ & $88.64 \%$ & $106.78 \%$ \\
Dry fish export (Price) & $140.63 \%$ & $73.36 \%$ & $63.56 \%$ & $90.08 \%$ \\
\hline
\end{tabular}

Source: Author's own calculation data from EPB (2006).

\section{Conclusion}

On the basis of findings of the study, it may be concluded that earnings from shrimp and dry fish (value, volume \& price) show positive growth per annum during the whole study period. It is also concluded that instability in exports of shrimp and dry fish (value, volume \& price) increased in the recent past. The increasing rate in forecasting of shrimp export for future five years is satisfactory. Forecasting of dry fish exports increases but rate of increase is very small. Well developed and systematic export promotion program is needed for shrimp and dry fish exports which will have a significant impact on both agriculture and economic development. By exporting shrimps and dry fishes in the world market, production needs to be increased which in turn can generate domestic demand by opening up employment opportunities. Considering the importance, the present study will undoubtedly be useful for Bangladesh government in policy formulation, planning and developing programs for improving growth of shrimp and dry fish, reducing instability in shrimp and dry fish export and determining the quantity of shrimp and dry fish to be exported from Bangladesh. These empirical findings can be significant source of information for the producers, traders, exporters, policy makers and researchers to build foundation for further research in this sector. 


\section{Recommendations}

The following recommendations are made for increasing shrimps and dry fishes export from Bangladesh:

$>$ The key factor of increasing shrimps and dry fishes export is to raise total production of shrimps and dry fishes. Every effort should be made to increase yield per fishery resources like cannel, river, beel, haor etc. This can be done by introducing modern technology, providing information to the fishermen how they increase production of shrimps and dry fishes and also encourage in exporting abroad.

$>$ Bangladesh should not try to increase the export price of shrimps and dry fishes because it may in turn lessen the export of them. She should try to produce shrimp and dry fishes at lower cost.

$>$ The key success factor of shrimp and dry fish exports from Bangladesh is her own quality production. Therefore, emphasis should be given on production and exports of quality shrimp and dry fish.

$>$ Comprehensive buffer stock scheme by the government with a view to stabilizing prices may, therefore, be attempted. Price support program should be ensured through effective policy measures.

$>$ Strong and committed endeavors are essential for market survey and market promotion for increasing the volume of export of both shrimp and dry fishes. For this, it is necessary for the government to come forward and organize international market promotion facilities on a regular basis.

\section{References}

Abbott, J.C. (1958). Marketing Problems and Improvement Programs, Rome, Foods and Agricultural Origination of the United Nations.

Awal, M.A., M.E. Haque and M.F. Imam. 1945-1949, 2006. Growth and Instability of Frozen Food, Shrimp and Fish Export from Bangladesh. Pakistan Journal of Biological Sciences 9 (10). ISSN 1028-8880.

Barua, P. and Alam. S. (2000): "Growth, Price Instability and Flexibility of Major Crops in Bangladesh". The Bangladesh Journal of Agricultural Economics. XXIII, 1\&2 (2000)-103-114.

BBS, (1972 to 2010). Statistical Yearbook of Bangladesh, Bangladesh Bureau of Statistics, Ministry of Planning, Government of the People's Republic of Bangladesh, Dhaka.

Belton, B. et al. 2011. "Review of aquaculture and fish consumption in Bangladesh". Studies and Reviews 2011-53. The World Fish Center. November 2011.

EPB, (1972 to 2011). Bangladesh Export Statistics. Export Promotion Bureau, Ministry of Commerce, Government of Bangladesh, Dhaka.

Quddus, M.A. and Akbar, M.A. (1994). "Marketing of Fish by Intermediaries in Netrokona District: An Empirical Analysis". Bangladesh Journal of Training and Development 7(1):24-25.

Rahman, F. (2001): "An Economic Analysis of Shrimp Processing firms in Some Selected Areas of Khulna District". Unpublished M.S. Thesis, Department of Agricultural Economics, Bangladesh Agricultural University, Mymensingh.

Sabur, S.A., Palash, M.S., Awal, M.A. and Rahman, K.T. 2010. Shrimp export from Bangladesh: Effect of war and trade liberalization. Bangladesh Agricultural University 8(1): 127-132.

Tasnoova, S. Yukata, T. and Iwamoto, I. (2010): "Market Structure and Procurement System of Shrimp Export Industry in Bangladesh". Dept. of Agricultural Economics, Faculty of Agriculture, Kagoshima University, Japan. 